\title{
Cree Fish Names from Eastern James Bay, Quebec
}

\author{
FIKRET BERKES ${ }^{1}$ AND MARGUERITE MACKENZIE ${ }^{2}$
}

\section{INTRODUCTION}

This paper provides a synthesis of Cree fish names as used in the eastern James Bay area communities of Mistassini, Waswanipi, Nemaska, Rupert House, Eastmain, Wemindji (Paint Hills or Nouveau Comptoir), Fort George and Great Whale (Poste-de-la-Baleine). These northern Quebec Cree constitute a relatively homogenous cultural group, and have been the subject of many studies, especially since 1972 in relation to the James Bay hydro-electric project. Information on Cree fish names in some communities in this area has been published (Table 1), but the material has not been compared and no standard orthography was used. A systematic study is important in part because some fish species of the area have elevated levels of mercury, and a questionnaire-based harvesting study is being made in relation to the James Bay and Northern Quebec Agreement signed in 1975 and proclaimed in 1977 . It is therefore important to identify the species correctly, and to check whether Cree fish names actually refer to species as recognized by western science.

\section{METHODS OF STUDY}

Fish names were compiled in three ways: actual identification of the fish during field studies; by interviews with tallymen (senior hunters in charge of registered traplines); and by interviews with selected informants of known expertise for identifications and proper spelling of names in Cree syllabics.

Field identifications were made in Fort George and Eastmain during ongoing studies of fisheries biology and human ecology. Interviews with tallymen, who are people respected among the Cree as experts on the local environment, were made with a subsample of about half the tallymen in each of the communities of Fort George, Wemindji, Rupert House and Great Whale. In the remaining Cree communities of Waswanipi, Nemaska and Mistassini, and in the Naskapi Band at Schefferville, information was obtained only by interviews with selected informants. In group and individual interviews, the identification book, Freshwater Fishes of Eastern Candda (Scott, 1967) was used, with supplementary material from other texts and field guides. \footnotetext{
3A1

'Institute of Urban \& Environmental Studies, Brock University, St. Catharines, Ontario, L2S

'Department of Linguistics, Memorial University, St. Johns, Newfoundland.
} 


\section{ORTHOGRAPHY OF CREE NAMES}

All the names of fish in this paper have been written in a phonemic orthography which is similar to those in current use among Algonkian linguists (Mailhot, 1975; Wolfart, 1973).

The use of a standardized writing system for all the Cree names will minimize the potential confusion which results from the proliferation of individual writing systems. Table 1 demonstrates how the same name for a fish may appear to be different words when written by different authors. It is hoped that the provision of syllabic equivalents will be of use to those scholars who wish to work directly with Cree speakers.

The consonants used in this orthography are $p, t, c h, k, s, s h, h, m, n, l, w, y$. In the Cree language there is no distinction made between $\mathrm{p} / \mathrm{b}, \mathrm{t} / \mathrm{d}, \mathrm{ch} / \mathrm{j}, \mathrm{k} / \mathrm{g}$ as there is in English. Both are acceptable variants of the same sound which will always be written as $p, t, c h, k$, respectively. Other consonants are pronounced as in English.

The vowel system consists of long vowels $i, e, \grave{a}, u$ and short vowels $i, a, u$. The English equivalents are as follows:

$$
\begin{gathered}
\text { i - eat, beet } \\
\text { à - at, cat } \\
\text { ù - too, boot } \\
\text { e - ever, ate }
\end{gathered}
$$

$$
\begin{gathered}
\mathrm{i}-i \mathrm{t}, \mathrm{bit} \\
\mathrm{a}-u \mathrm{p}, \mathrm{c} u \mathrm{p} \\
\mathrm{u}-\mathrm{p} u \mathrm{t}, \mathrm{book}
\end{gathered}
$$

The fish names are written as they would appear in slow, careful pronunciation. The pronunciation will vary slightly in the more rapid speech of ordinary conversation. The Cree syllabic writing system can be transliterated directly into this alphabetic system.

\section{DIALECT VARIATION}

There is general agreement between results of previous investigations and the present study. Table 2 is a summary of the Cree fish names in a standardized orthography for each of the communities. The names given here represent a "consensus opinion" among knowledgeable informants. There are, however, often acceptable variants of a species name as Feit's (1978) work demonstrates; Table 2 includes some of the more common variants but does not list the full range.

In the northern communities of Great Whale, Fort George, Wemindji and, to some extent, Eastmain, the e vowel is not used but is replaced by $a$. The $e$ to $a$ vowel shift is one dialect difference which divides the northern and southern areas and which therefore affects the spelling of fish names.

A second, cross-cutting dialect split exists between the communities of Rupert House, Eastmain, Wemindji, Fort George and Nemaska on one hand and Waswanipi, Mistassini and Great Whale on the other. While speakers in the former set of villages use two distinct phoneme $s$ and $s h$, speakers in the latter villages use only $s$ as follows: Rupert House, chinushew (pike); Fort George, chinushàw; Great Whale, chinusàw; and Mistassini, chinusew. 
TABLE 1. Fish names of the eastern James Bay Cree previously reported in the literature (Authors' original spelling is retained. Scientific names after Scott and Crossman 1973)

arctic char, Salvelinus alpinus

brook trout (speckled trout), Salvelinus fontinalis

lake trout, Salvelinus namaycush

whitefish, Coregonus clupeaformis

cisco, Coregonus artedii

burbot (ling), Lota lota

white sucker, Catostomus commersoni

longnose sucker (red sucker),

Catostomus catostomus

sturgeon, Acipenser fulvescens

walleye (pickerel/doré),

Stizostedion vitreum

yellow perch, Perca flavescens

pike, Esox lucius

mooneye/goldeye, Hiodon spp.

\section{Waswanipi}

Feit

(1978)

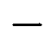

mašamekos

mašamek

nemeks

nemakos

atekamek

atikamek

oćulapi

očulapies

miakatu

namapi

mikoašan

mikošao

nemeo

okaš

osaoeo

ošaoeo

osaoeoš

ošaoes

činošeo

cinosa

nepakatso

nepakatsu

nipakatišao

Waswanipi
Magnin
(1964)

Nemaska

Lebuis

(1971)

Mistassini

Tanner

(in press)

a:wana:ns

mašumèk

ma:samekw

némèkus

attikumèk

očolibis

outioulibi

miakoto

némébi

mikoachan

miakoto

némèbi

mokhwašaw

nameo

ouchavatch-

oukatch

chavoo

némèw

okaš

$-$

tchinouchao

cinušèw

napakatcho namekus

atihkamekw

-

mi:ya:katuy

namepi:

makwayseu:

namew

u:ka:w

u:ka:s

cinusew 
TABLE 2. Cree fish names in standard orthography

\begin{tabular}{|c|c|c|c|c|c|c|c|c|}
\hline & $\begin{array}{l}\text { Great } \\
\text { Whale }\end{array}$ & $\begin{array}{l}\text { Fort } \\
\text { George }\end{array}$ & Wemindji & Eastmain & $\begin{array}{l}\text { Rupert } \\
\text { House }\end{array}$ & Waswanipi & Nemaska & Mistassini \\
\hline arctic char & sùsàsù & sùsàsù & - & - & - & - & - & - \\
\hline $\begin{array}{l}\text { landlocked } \\
\text { salmon }\end{array}$ & unàw & unàw & - & - & - & - & 一 & - \\
\hline speckled trout & màsimàkus & màsimàkush & màsimàkush & màsimàkush & màsimekush & màsimekush & màsimekw & $\begin{array}{l}\text { màsimekw } \\
\text { màsimekush }\end{array}$ \\
\hline $\begin{array}{l}\text { lake trout } \\
\text { whitefish }\end{array}$ & $\begin{array}{c}\text { kùkamàs } \\
\text { kùkamàw } \\
\text { atihkamàkw }\end{array}$ & $\begin{array}{l}\text { kùkamàsh } \\
\text { kùkamàw } \\
\text { atihkamàkw }\end{array}$ & $\begin{array}{c}\text { kùkamàsh } \\
\text { atihkamàkw }\end{array}$ & $\begin{array}{c}\text { kùkamesh } \\
\text { atihkamekw }\end{array}$ & $\begin{array}{l}\text { kùkamesh } \\
\text { atihkamekw }\end{array}$ & $\begin{array}{c}\text { namekush } \\
\text { atihkamekw }\end{array}$ & $\begin{array}{c}\text { namekush } \\
\text { atihkamekw }\end{array}$ & $\begin{array}{c}\text { namekush } \\
\text { atihkamekw }\end{array}$ \\
\hline cisco & nùtimiwàsù & nùtimìwàsù & nùtimiwàsù & nutimiweshish & nùtimiwesù & $\begin{array}{l}\text { utùlipì } \\
\text { uchùlipishh }\end{array}$ & utùlipish & - \\
\hline $\begin{array}{l}\text { burbot } \\
\text { white sucker }\end{array}$ & $\begin{array}{c}\text { mìy } \\
\text { miyàhkatù } \\
\text { iyichàw }\end{array}$ & $\begin{array}{l}\text { miyàhkatù } \\
\text { nimàpi }\end{array}$ & $\begin{array}{c}\text { miyàhkatù } \\
\text { nimàpì }\end{array}$ & $\begin{array}{c}\text { miyàhkatù } \\
\text { namepì }\end{array}$ & $\begin{array}{c}\text { miyàhkatù } \\
\text { namepì }\end{array}$ & $\begin{array}{c}\text { miyàhkatù } \\
\text { namepì }\end{array}$ & $\begin{array}{c}\text { mìyàhkatù } \\
\text { namepi }\end{array}$ & $\begin{array}{c}\text { miyàhkatù } \\
\text { namepí }\end{array}$ \\
\hline $\begin{array}{l}\text { red sucker } \\
\text { sturgeon }\end{array}$ & $\begin{array}{c}\text { nimàpì } \\
-\end{array}$ & $\begin{array}{l}\text { mihkumàpì } \\
\text { nimàw }\end{array}$ & $\begin{array}{c}\text { mihkwàshàw } \\
\text { mihkuchikàsh } \\
\text { nimàw }\end{array}$ & $\begin{array}{c}\text { mihkuchikàsh } \\
\text { mihkwàshew } \\
\text { namew }\end{array}$ & $\begin{array}{c}\text { mihkuchikàsh } \\
\text { mihkwàshew } \\
\text { namew }\end{array}$ & $\begin{array}{c}\text { mihkwàsew } \\
\text { namew }\end{array}$ & $\begin{array}{c}\text { mihkusew } \\
\text { namew }\end{array}$ & $\begin{array}{c}\text { mihkusew } \\
\text { namew }\end{array}$ \\
\hline walleye & - & ukàw & ukàw & ukàw & ukàw & ukàsh & ukàsh & $\begin{array}{l}\text { ukàsh } \\
\text { ukàw }\end{array}$ \\
\hline pike & chinusàw & chinushàw & chinushàw & chinushew & chinushew & chinushew & chinushew & chinusew \\
\hline hiodons & - & - & - & - & napakachisù & napakachisù & napakachisù & napakachisù \\
\hline perch & - & - & - & ùsàwàsh & usàwew & usàwew & - & - \\
\hline
\end{tabular}

Note: The authors are prepared to supply copies of the table using syllabic script for readers who are especially interested. 
In addition to these dialect variations, there is within each coastal community a division of families into 'coasters' and 'inlanders'. The 'coasters' traditionally hunt near the coast of James Bay and exploit maritime resources, while 'inlanders' traditionally only hunt and trap during winter in the inland regions. This social distinction is reflected in a sub-dialectal difference, as shown in examples such as the use of the terms mihkuchikàsh and mihkwàshew in Eastmain for longnose sucker by 'coastal' and 'inlanders' respectively.

The dialect of the coastal villages as a group contrasts with that of the three inland communities of Nemaska, Waswanipi and Mistassini. Terms used by these coastal villages for both cisco and lake trout are unrelated to the terms used by the inland communities for these species (Table 2). Also, the term for walleye is usually used in the diminutive form ukàsh in the inland communities and in the nondiminutive form ukàw in the other villages.

Fish names of the eastern James Bay Cree appear to be similar to those used by their neighbors, the western James Bay Cree and the Naskapi. According to fish names reported by Honigmann (1962) from Attawapiskat, only the term for burbot differs substantially from names in Table 2.

In standard orthography, Naskapi fish names from Schefferville may be written as follows: brook trout, matimàkush; lake trout, kùkamàsh; whitefish, atihamàkw; burbot, mìy; white sucker, ìyichàw; longnose sucker, mïhwàshï; and pike, chinusàw.

The terms in use at Great Whale for burbot and white sucker reflect historical links with the Naskapi people of Schefferville. Both these groups use mìy and ïyichàw respectively for these two species instead of mìyàhkatù and nimàpi which all other Cree communities use.

In addition to the system of standard names, the Cree have two other nomenclature systems, one based on nicknames and the other on location names where those fish are caught. As with most animals (and for that matter people) most fish species have nicknames. Examples: mikhuskitàw ( $=$ red belly) for brook trout in spawning condition with red-coloured ventral side (Fort George); uchimàw (literally "the boss", translateable as "the prince of waters") for pike (Rupert House). In Rupert House, some cisco are called kàcikàsukamekw, which actually refers to a location between two islands where cisco are caught.

Some common English names of animals may be traced to the Cree language. Hohn (1973) pointed out that Cree names have been the basis of common English names of three species of mammals and birds: moose, whiskey jack and wavey. Among fish species, tulibee, the common English name for Coregonus artedii used in northern Ontario and the Western provinces, is attributed to the Cree (Scott and Crossman 1973, p. 243). The scientific name for lake trout, namaycush, is an Indian name (Scott and Crossman 1973, p. 227), almost certainly Cree. The common name for land-locked Atlantic salmon in Quebec, ouananiche, is of Cree-Montagnais origin. 
There is a Cree name, and a unique Cree name for each of the fourteen major species recognized by biologists. These species (Table 1) do not represent the entire fish fauna of the region, but they are the major species caught by the Cree. According to Magnin (1977) in the eastern James Bay area, a total of 31 species of fish occur; many of them are "forage" species, too small to be caught by gillnets used by the Cree. There are Cree names for some of these species, but Table 2 includes only those species on which systematic data were collected.

The geography of Cree names closely parallels the known distribution of the species, as summarized by Scott and Crossman (1973). For example, there is no sturgeon and walleye in the Great Whale area, no char and salmon south of Fort George, and no yellow perch north of Eastmain. However, Cree fishermen often do recognize some of the more important fish even though these fish are not normally found in their area. For example, arctic char is known in Eastmain, Wemindji and Schefferville, and lake trout is known in Waswanipi and Eastmain even though very few have ever been caught there.

There are two taxonomic issues that pose problems to Cree ethnoichthyology. The first is the distinction between yellow walleye (Stizostedion vitreum), and sauger (S. canadense), found occasionally in southern Waswanipi area. According to Magnin (1964) the Waswanipi make a descriptive distinction between the two calling one "yellow ukàsh" and the other, "dark ukàsh". According to Feit (pers. comm.), the distinction is probably not a difference in the formal names of the two species. The second problem concerns the identification of goldeye, Hiodon alosoides vs. mooneye, $\boldsymbol{H}$. tergisus. There was no formal distinction in the Waswanipi Cree names of the two, and informants did not report a knowledge of the difference. It appears, however, that after biologists pointed it out, the difference was quickly picked up by some Cree fishermen (Feit pers. comm.).

In turn, Cree ethnoichthyology poses two problems to biological science. These are cases in which the Cree make a formal distinction which is not at present recognized by science. The usual term for the Atlantic salmon (Salmo salar), unàw (uyànish in Schefferville), refers to the landlocked form of the species. The Cree of Great Whale and Naskapi of Schefferville make a distinction between unàw and the sea-run form, uchàsumàkw. Tanner (pers. comm.) reports that some inlander Crees of Fort George recognize uchàsumàkw as a fish found in the Caniapiscau River but not in lakes.

The second case involves the Coregonus group. Weinstein (1976) reported a form of land-locked cisco-like fish which he called wu-tschick-a-chawsa. It was reported to Tanner (pers. comm.) that a fish called wuchukachesù, with a head like a cisco and a body like whitefish, occurred in a lake at $76^{\circ} 42^{\prime} \mathrm{W} ; 53^{\circ} 47^{\prime}$ $\mathrm{N}$. This lake will be inundated by the forebay of LG-3 dam. Ciscoes are known to be a taxonomically complicated group, but at present no sub-species of Coregonus artedii are recognized in eastern Canada. An alternative possible explanation of this fish is that it may be a cross between $C$. artedii and $C$. clupeaformis. 
In addition to these biological research possibilities, this brief study suggests that there is a need to study the classification systems of the Cree using ethnoscientific techniques. It cannot be assumed that the Cree system of classification is completely homologous with the scientific one, even though there appears to be a high degree of similarity with respect to species identifications of fish. Two of the three Cree naming systems, nicknames and location-based names, still remain to be examined. More work is needed on the standard naming system and the higher taxonomic classifications should be studied.

\section{ACKNOWLEDGEMENTS}

We thank our colleagues, H. A. Feit and A. Tanner and of course our many informants. The work reported in this paper grew out of discussions with fishermen and those in charge of Native Harvesting Research and mercury programs. It was carried out during the course of other studies, and made possible with the cooperation of the local band councils.

\section{REFERENCES}

FEIT, H.A. (1978) Waswanipi Realities and Adaptations. Resource Management and Cognitive Structure. Ph.D. Thesis, Department of Anthropology, McGill University, Montreal.

HOHN, E.o. 1973. Mammal and bird names in the Indian languages of the Lake Athabasca area. Arctic 26: 163-171.

honigmanN, J.J. 1962. Foodways in a Muskeg Community. Ottawa: Northern Coordination and Research Centre, NCRC-62-1.

LEBUIS, F. 1971. Le Complexe Culturel de la Peche de Subsistance à Némiska, al Nouveau-Québec. Thèse de maîtrise, Départment d'Anthropologie, Université de Montreal.

magnin, E. 1964. Premier inventaire de la faune ichtyologique du lac et de la rivière Waswanipi, centre-ouest du Québec. Naturaliste Canadien 91:273-308.

MAGNIN, E. 1977. Ecologie de Eaux Douces du Territoire de la Baie James. Montreal: Société d'énergie de la Baie James.

MAILHOT, JOSE. 1975. Standardisation de L'orthographe Montagnaise. Chicoutimi: Université de Québec.

ScoTT, w.B. 1967. Freshwater Fishes of Eastern Canada. Second Edition. Toronto: University of Toronto Press.

SCOTT, W.B. and CROSSMAN, E.J. 1973. Freshwater Fishes of Canada. Ottawa: Fisheries Research Board of Canada, Bulletin No. 184.

TANNER, A. (in press) Bringing Home Animals. Religious Ideology and Mode of Production of the Mistassini Cree Hunters. St. John's: Memorial University, Institute of Social and Economic Research and London: Hurst.

WEINSTEIN, M.W. 1976. What the Land Provides. An Examination of the Fort George Subsistence Economy and the Possible Consequences on it of the James Bay Hydroelectric Project. Montreal: Grand Council of the Cree (of Quebec).

WOLFART, H. CHRISTOPH 1973. Plains Cree: A Grammatical Study. Philadelphia: American Philosophical Society. 